\title{
The American Phytopathological Society 3rd I. E. Melhus Graduate Student Symposium: New Thesis Research Contributions to Plant Disease Epidemiology
}

\author{
Stella Melugin Coakley and Don E. Mathre
}

First author: Department of Botany and Plant Pathology, Oregon State University, Corvallis 97331; and second author: Montana State University, 208 Ag Biosciences, Bozeman 59717.

Accepted for publication 27 December 2002.

The I. E. Melhus Fund was established in The American Phytopathological Society Foundation with gifts from Dr. and Mrs. William C. Paddock, Mr. and Mrs. Walter Goeppinger, and Dr. and Mrs. Jack Wallin and enhanced by additional funds from the Foundation. Irving E. Melhus was a renowned teacher, an innovative researcher, and an outstanding departmental administrator at Iowa State University. His breadth of experience, contributions to the practical application of disease control, classic work on root pathogens of Iowa crops, and his visionary work on corn improvement epitomize a truly pioneer plant pathologist. In 1939, he coauthored the well-written textbook, The Elements of Plant Pathology, with Dr. G. C. Kent. His service to The American Phytopathological Society further exemplified his leadership in and commitment to the profession of phytopathology. He was president of APS in 1926 and was elected a Fellow in 1965 . He was a member of the Iowa Academy of Sciences, the Botanical Society of America, and a fellow of the American Association for the Advancement of Science. Dr. Melhus was not only an outstanding plant pathologist, he was an inspiring mentor and an engaging personality with a keen sense of humor.

Initially used to sponsor individual speakers (I. E. Melhus student speakers presented in 1997, 1998, and 2000), the first symposium, sponsored by the Epidemiology Committee, was funded in 1999. The second student speaker symposium, organized by the Plant Disease Losses Committee, was held in 2001 and published in 2002. The papers published here are two of the three papers presented in the 3rd I. E. Melhus Graduate Student Symposium: New Thesis Research Contributions to Plant Disease Epidemiology. These speakers were chosen through a competitive process by the Epidemiology Committee and presented their papers at the 2002 Annual Meeting of The American Phytopathological Society. Effective for 2003, selection of the committees to organize the annual I. E. Melhus symposium is now the responsibility of the APS Scientific Programs Board. 